\title{
Knowledge sharing, problem solving and professional development in a Scottish Ecosystem Services Community of Practice
}

\author{
Marc J. Metzger ${ }^{1}$ (D) Jan Dick ${ }^{2} \cdot$ Abi Gardner $^{1} \cdot$ Chloe Bellamy $^{3} \cdot$ Kirsty Blackstock $^{4} \cdot$ Calum Brown $^{1,5}$. \\ Rachel Chisholm ${ }^{1}$. Phoebe Cochrane ${ }^{6}$. Joanna Drewitt ${ }^{7}$. Alessandro Gimona ${ }^{4}$ - Alison Hester ${ }^{4} \cdot$ Scot Mathieson $^{8}$. \\ Maria Nijnik ${ }^{4}$ Alistair McVittie ${ }^{9} \cdot$ Michal Petr $^{3} \cdot$ Ron Smith $^{2} \cdot$ Mike Smith $^{10}$
}

Received: 17 May 2018 / Accepted: 24 June 2019 / Published online: 20 July 2019

(C) The Author(s) 2019

\begin{abstract}
The ecosystem services framework has now been embodied in policy and practice, creating the need for governance structures that allow science, policy and practice to come together and facilitate shared learning. We describe five years of progress in developing an Ecosystem Services Community of Practice in Scotland, which brings together over 600 individuals from diverse constituencies to share experiences and learn from each other. We consider the 'community' and 'practice' aspects to demonstrate the benefits of establishing an Ecosystem Services Community (ESCom). We also demonstrate how the journey involved in the creation and continuing evolution of ESCom has proved valuable to researchers, policy-makers, practitioners and students and as such has contributed to social learning. We reflect on challenges, given the voluntary nature, absence of formal institutional support and emergence of initiatives focusing on overlapping topics. Based on our experience, we provide ten recommendations to help future ecosystem services communities of practice.
\end{abstract}

Keywords Community of Practice $\cdot$ Scotland $\cdot$ Knowledge exchange $\cdot$ Stakeholder engagement

Joanna Drewitt has recently retired from Scottish Government.

Electronic supplementary material The online version of this article (https://doi.org/10.1007/s10113-019-01537-0) contains supplementary material, which is available to authorized users.

Marc J. Metzger

marc.metzger@ed.ac.uk

Jan Dick

jand@ceh.ac.uk

Abi Gardner

agardner022@gmail.com

Chloe Bellamy

chloe.bellamy@forestresearch.gov.uk

Kirsty Blackstock

kirsty.blackstock@hutton.ac.uk

Calum Brown

calum.brown@kit.edu

Rachel Chisholm

rachel.chisholm@ed.ac.uk

Phoebe Cochrane

phoebe@ scotlink.org

\author{
Alessandro Gimona \\ alessandro.gimona@hutton.ac.uk \\ Alison Hester \\ alison.hester@hutton.ac.uk \\ Scot Mathieson \\ scot.mathieson@sepa.org.uk \\ Maria Nijnik \\ maria.nijnik@hutton.ac.uk \\ Alistair McVittie \\ alistair.mcvittie@sruc.ac.uk \\ Michal Petr \\ michal.petr@forestresearch.gov.uk \\ Ron Smith \\ ris@ceh.ac.uk \\ Mike Smith \\ mikesmithecosol@gmail.com
}

Extended author information available on the last page of the article 


\section{Introduction}

Over the last decade, ecosystem services have moved from an academic concept to a framework embodied in policy and practice (Beaumont et al. 2017; Dick et al. 2018; Jax et al. 2018). An important reason for the rapid rise in prominence is the holistic nature of the concept, which embraces a socioecological systems approach (Melnykovych et al. 2018) and bridges traditional sectoral and disciplinary siloes by explicitly incorporating human decisions and values in natural resource management (Díaz et al. 2015; Faivre et al. 2017; Sarkki et al. 2017). The ecosystem services framework has the potential to act as a transdisciplinary boundary object, engaging different disciplines and non-scientists in shaping and achieving societal goals (Waylen et al. 2013; Abson et al. 2014; Ainscough et al. 2019). A prerequisite for transdisciplinary research (Mauser et al. 2013; Baumgärtner et al. 2008) is to bring researchers, decision-makers and practitioners together (Nesshöver et al. 2016) by creating a space to align motivations and build trust (Schoonhover et al. 2019). It is therefore important to identify governance structures that allow these distinct constituencies to come together and facilitate shared learning.

This paper reflects how an informal and transdisciplinary community focused around the policy-science-practice of ecosystem services in Scotland was created and how it has contributed to knowledge sharing, problem solving and professional development. The Ecosystem Services Community Scotland (ESCom) was established in 2013, and has attracted over 600 researchers, decision-makers and practitioners to attend and contribute to a diverse range of activities and events. We, the authors, were the initiators and organisers of ESCom. Here, we consider the successes and challenges over the last six years - supported by data and quotes from community members - to identify lessons learnt and recommendations for initiating and sustaining a transdisciplinary ecosystem services community. Although the majority of the authors are academics, their role within ESCom is not as analytical observers, but as participants in mutual learning and development. Researching the development of ESCom is not the primary motivation for ESCom organisers, but developing this research paper created the opportunity to systematically assess what ESCom has achieved and what recommendations it suggests for the wider community. This is a developmental evaluation approach undertaken by 'insiders', with all the subjectivities that this entails (Patton 2011), so to ensure analytical rigour, we have structured our critical reflection using Community of Practice (CoP) literature (Wenger et al. 2002).

A CoP is defined by Wenger et al. (2002:4) as 'a group of people who share a concern, a set of problems, or a passion about a topic, and who deepen their knowledge and expertise in this area by interacting on an ongoing basis'. As such, a $\mathrm{CoP}$ provides opportunities for sharing information and experiences and allows members to learn from each other, to develop themselves personally and professionally (Lave and Wenger 1991) and to contribute to the progress of the topic (Brown and Dugin 2001; Wenger et al. 2002). The loose definition of the $\mathrm{CoP}$ concept makes it a widely applicable framework for social learning that has been successfully applied in various sectors, including private business, education, health and ecological restoration (Dendoncker et al. 2018). Whilst other theoretical frameworks exist-e.g. knowledge coproduction (Reed and Abernethy 2018) and multistakeholder deliberative platforms (Mulema and Mazur 2016) - the concept of a CoP was felt most useful for structuring our reflections because it explicitly recognises social networks and learning beyond a specific project and is rooted in a focus on practices.

There have been critiques of the $\mathrm{CoP}$ concept, both from a theoretical standpoint and among practitioners (Hughes et al. 2007a). From a theoretical perspective, there is the risk of connoting harmony and homogeneity and overlooking complex interwoven social contexts, disagreement and conflict (Hughes et al. 2007b). From a practical perspective, it can be challenging to find the balance between formality, to give the CoP legitimacy, and informality, to let it be a peer-oriented, self-governed partnership (Wenger et al. 2002). Nevertheless, there is much support for $\mathrm{CoP}$ as an approach that helps explain why and how social learning processes can improve policy implementation (Farnsworth et al. 2016) and focusses attention on learning in adaptive environmental management (Nursey-Bray et al. 2016). Therefore, we consider the CoP concept a useful lens to structure our reflections on the development and achievements of ESCom.

Of course, a strong tradition exists in academia of deepening knowledge and expertise by interacting on an ongoing basis (the core premises of a $\mathrm{CoP}$ ). In fact, academic societies - dating back to the establishment of the Royal Society in $1660^{1}$ - were established for this very purpose and can be seen as a form of CoP, especially when they have an explicit focus on stimulating transdisciplinary collaboration and demonstrating and promoting science to society. In recent years, various national and global societies have focused on ecosystem services (e.g. the British Ecological Society ${ }^{2}$ and the International Association for Landscape Ecology ${ }^{3}$ ), and specific new networks have been established including the Ecosystem Services Partnership ${ }^{4}$ (ESP) and the Future Earth project EcoServices ${ }^{5}$. Belgium has successfully established a national ecosystem services network (Dendoncker et al. 2018) and recent initiatives by ESP and Oppla ${ }^{6}$ are trying to facilitate

\footnotetext{
${ }^{1}$ www.royalsociety.org

${ }^{2}$ www.britishecologicalsociety.org

3 www.landscape-ecology.org; www.iale.uk

${ }^{4}$ www.es-partnership.org

${ }^{5}$ futureearth.org/projects/ecoservices

${ }^{6}$ www.oppla.eu
} 
web-based communities. But there are no examples or guidance to support the development of a regional ecosystem services CoP, which is a gap this paper tries to address.

Following a short description of the process of establishing ESCom, we consider in more detail the 'community' and the 'practice' aspects of the CoP. We end by reflecting on experience over the last six years and identify lessons learnt for ourselves and others.

\section{Establishing a Scottish Ecosystem Services Community of Practice}

Scotland has taken a proactive stance in adopting global and European norms and requirements for nature conservation and sustainable resource management. Claret et al. (2018) reviewed 212 Scottish policy documents and concluded that the ecosystem services framework has been actively integrated into most policy sectors. However, there are still persistent difficulties in turning ecosystem knowledge into concrete policy instruments, with a recurrent emphasis on the need for further research (Claret et al. 2018). To support its policy implementation, the Scottish Government funded a $£ 1.8$ million strategic environmental change research programme focusing specifically on ecosystem services (2011-2016). Around the same time, three major European research projects-OPERAs, OpenNESS and GREEN SURGE-were funded with a further $£ 1.5$ million to develop and test ways of applying the ecosystem services framework in Scotland between 2012 and 2017.

Realising the special opportunity of this substantial and sustained funding, researchers from four institutes and one university (Online Resource 1) looked to identify synergies and opportunities for collaboration. They agreed to establish a community for ecosystem services research, decisionmaking and natural resource management in Scotland that would aim to: (a) align Scottish ecosystem services research, to maximise benefits, identify synergies, and avoid duplication; (b) work with policy and practice to gain better understanding of user needs, provide relevant research, and achieve impact; and (c) organise and promote events to support knowledge exchange through a dedicated website. It was the addition of the second objective (working with policy and practice) that distinguished this community from existing academic-focused societies. Seven thematic working groups were initially established to stimulate more focused research collaboration within ESCom (Online Resource 2), though, in practice, many activities straddled working group remits.

ESCom was formally launched during a full-day free conference in April 2014, which attracted 68 delegates (33 research, 10 policy, 23 practitioners, 2 students). In addition to highlighting ongoing research and a supportive address by Scotland's environment Minister, the event focused on two central questions: 'What would you like to gain from ESCom?' and 'What could you contribute to ESCom?'. Facilitated break-out discussions confirmed a strong demand and interest in an ecosystem services $\mathrm{CoP}$ and provided good suggestions for moving forward. Overall, participants were supportive of the reason to form a $\mathrm{CoP}$ around the concept of ecosystem services. Online Resource 3 provides the conference report, and specific motivations to participate in ESCom are described in more detail in the "Participation" section below.

Following discussions at the launch conference, other organisations were asked to join the ESCom management group-ESCom Central - to help shape direction and activity. Non-Governmental Organisation (NGO) and policy communities were specifically targeted to ensure representation from ESCom's envisaged constituency, resulting in core representation from nine organisations (Online Resource 1). ESCom Central had two co-chairs, a network manager providing administrative and communication support, and thematic leads for four process areas (embracing the thematic working groups) which together span the policy cycle for ecosystem services (Online Resource 2). The process area leads were charged with identifying research gaps and opportunities for ESCom activities.

ESCom Central initially met approximately three times a year and its broad and inclusive membership provided a sounding board for planning ESCom activities (see below). However, it proved difficult to sustain meeting attendance, and several non-research members left the group because its activities were not core to their job remit but continued to support ESCom by attending events. There were further challenges to maintain the level of activities when the projectfunded network manager left her post at the end of her contract in 2017. A simplified governance structure was recently agreed in 2018 (Online Resource 2) whereby meetings are restricted to two per year, and communication and administrative support is provided through a student placement.

\section{A community}

The community provides the social fabric of learning whilst fostering relationships based on mutual respect and trust by enabling a mixture of intimacy and openness to enquiry (Wenger et al. 2002). To build a community, members must interact regularly and feel part of a recognisable entity. We therefore reflect in some detail on participation and identity, drawing on the summary report of discussions during the launch conference (Online Resource 3), an open-ended questionnaire circulated at the launch conference $(n=35)$, and a recent web-based survey ( $n=50$; Online Resource 4$)$. Quotes from the questionnaire and survey are used for illustration, and Table 1 presents five invited reflections from policy, practice 
Table 1 Statements summarising the value of Ecosystem Services Community Scotland (ESCom) to five non-research community members who have attended five or more events and represent a diverse range of participants (i.e. NGO, government agency, local authority, commercial forestry, and postgraduate students)

Member Value of ESCom to the member

NGO project officer

(attended 5 events)

Government agency partnerships officer

(attended 8 events)

Local authority team leader sustainability policy and research (attended 5 events)

Technical director Confederation of Forestry Industries

(attended 9 events)

MSc Ecosystem Services graduate of The University of Edinburgh (attended 6 events)
RSPB Scotland's ambitions in the Inner Forth have always been to make more space for nature in what is a very human landscape. To achieve this it has been necessary to consider the services provided by the habitats we are attempting to create, to ensure they are valued by a range of stakeholders. ESCom has been vital in enabling us to understand the ecosystem services this work can provide, as well as highlighting new and novel ways to communicate our work to partners and stakeholders. This has helped us build more support and deliver wildlife conservation on a truly landscape scale.

As a practitioner, I have valued the contribution that ESCom has made to my project work applying the ecosystem services framework. For example, the innovative approach taken in developing a 10-year management plan for the Pentland Hills Regional Park was significantly enhanced through the added experience and support of ESCom members. Being part of the ESCom community instilled in me the confidence to apply relatively complex, holistic and inclusive approaches to land use and management decision making.

Despite the expectation for evidence-based policy making it is often difficult for local authorities to access academic research. ESCom has given my team the opportunity to learn from and collaborate with the researchers to jointly address the challenges and opportunities of operationalising the ecosystem services approach in policy-making. ESCom operates at the right scale for building effective partnerships which facilitates trust-building and cooperation, enabling us to share our work with other policy-makers and practitioners in Scotland.

ESCom has been an important opportunity for Confor to speak with, and listen to, a wide range of individuals who are working in the fields of Natural Capital and Ecosystem Services. The ESCom visit to Jerrah (a 1000 hectare new commercial woodland near Stirling) in summer of 2016, was a great example of enabling those important conversations between researchers and practitioners to take place and helping us better understand the trade-offs in delivering multi-functional land-use.

ESCom network provided me the first insight into how the concept was being researched, understood and used by a wide range of people and organisations. There were (and still are) aspects of the concept unresolved and not understood. But during the time of my studies, ESCom provided (and still does) a valuable forum where ES stakeholders can come to exchange ideas and experiences, learn from one another and sometimes disagree but most importantly in a space promoting dialogue rather than a right or wrong debate. and student community members who attended five or more ESCom events. The responses from these core members illustrate how the CoP encouraged sharing knowledge outside the research community and the relationships that made such knowledge sharing useful.

\section{Participation}

Participation in a CoP is determined by combined factors relating to the domain, the wish to join and interact within a community, and an interest in developing or understanding common or best practice (Wengner et al. 2002). We describe participation in ESCom by exploring what members feel ESCom can provide, how members can contribute and how community membership can be understood. We separate responses into the following: researchers (Science); decisionmakers in national government and government agencies (Policy); practitioners, consultants, and local authority regulators (Practice); and students who will form the next generation of researchers, policy-makers and practitioners (Students).

Discussions at the launch conference (summarised in Online Resource 3) identified a range of benefits that ESCom can provide to its members. These include the following: the opportunity to have a forum for debate, learning and 
sharing best practice; the potential for co-design and codelivery of transdisciplinary research; opportunities to organise capacity-building and training workshops; field trips to demonstration sites; and the prospect of a resource hub with synthesis information and news. In subsequent discussions, ESCom members suggested that they could support ESCom by organising and hosting events, co-badging activities with ESCom branding, publicising ESCom in their networks and sharing data, methods and experiences.

Table 2 summarises the responses to the two open-ended survey questions. The most frequently mentioned benefits of ESCom across science, policy and practice are the forum for debate and sharing best practice, associated networking opportunities and the synthesis and overview of topics. These benefits are exemplified by these quotes from the 2016 survey:

Helped me to develop my knowledge and experience of ecosystem service practice through sharing at events. Providing great networking opportunities.-Public sector agency

Helped connect with others working on similar things. Enabled the piloting of research ideas and learning what others have been up to in the field. A place to learn and share ideas.-Researcher

Table 2 Responses to two open-ended survey questions asked at the end of the Ecosystem Services Community Scotland (ESCom) launch conference in 2014 and in 2018 via an online survey, summarised for common themes identified in the 2014 conference launch conference
Interestingly, there is a marked difference in how respondents wanted to support ESCom. Initially the main response was by researchers willing to share data, methods and experiences. But in the recent survey, this data and methods sharing was hardly mentioned. Instead the focus was on organising and participating in events and publicising ESCom. This shift on what ESCom could do for members, towards what members could for ESCom could indicate a greater sense of community membership.

CoPs have fuzzy boundaries and different levels of participation, with a self-selected membership based on expertise or interest for a topic (Wenger et al. 2002). As such, it is difficult to determine a formal membership. The best indication of participation is probably attendance at ESCom activities (Fig. 1), where we can distinguish between the active core group of approximately 35 individuals who are ESCom Central members, those who have organised events and/or those who frequently attend events (35 individuals have attended 5 or more events in $4 \frac{1}{2}$ years). A larger group can be considered to be active members, regularly attending events and occasionally contributing to ESCom by presenting work or contributing blogs or news items (66 individuals attended between 3 and 5 events). Finally, there is a substantial peripheral group of over 500 individuals who have participated in just one or two events and, perhaps, engaged with ESCom as one of its 700 Twitter followers.

report (Online Resource 2). The surveys are described in Online Resource 4. Numbers represent percentage of respondents who mentioned the theme, per category (Science, Policy, Practice, Students)

\begin{tabular}{|c|c|c|c|c|c|c|c|}
\hline & \multicolumn{3}{|c|}{2014 survey } & \multicolumn{4}{|c|}{2018 survey } \\
\hline & $\begin{array}{l}\text { Science } \\
n=18\end{array}$ & $\begin{array}{l}\text { Policy } \\
n=5\end{array}$ & $\begin{array}{l}\text { Practice } \\
n=6\end{array}$ & $\begin{array}{l}\text { Science } \\
n=21\end{array}$ & $\begin{array}{l}\text { Policy } \\
n=6\end{array}$ & $\begin{array}{l}\text { Practice } \\
n=16\end{array}$ & $\begin{array}{l}\text { Student } \\
n=5\end{array}$ \\
\hline \multicolumn{8}{|l|}{ What can ESCom do for you? } \\
\hline A forum for debate and learning sharing best practice & 22 & 20 & 17 & 43 & 0 & 25 & 0 \\
\hline Collaborative research planning and delivery & 6 & 0 & 0 & 5 & 0 & 6 & 0 \\
\hline Capacity building and training workshops & 6 & 0 & 0 & 0 & 0 & 0 & 0 \\
\hline Field trips to demonstration sites & 0 & 0 & 0 & 0 & 0 & 0 & 20 \\
\hline Synthesis and overview of topics & 17 & 40 & 17 & 10 & 50 & 13 & 40 \\
\hline Online resource hub with case studies, news and information & 6 & 20 & 17 & 5 & 0 & 0 & 0 \\
\hline Networking opportunities & 33 & 0 & 50 & 33 & 33 & 25 & 40 \\
\hline \multicolumn{8}{|l|}{ What can you do for ESCom? } \\
\hline Organise and host events & 6 & 0 & 0 & 48 & 17 & 0 & 20 \\
\hline Co-badge activities with ESCom & 0 & 0 & 0 & 0 & 0 & 6 & 0 \\
\hline Collaborate with students & 11 & 20 & 0 & 0 & 0 & 6 & 0 \\
\hline Share data, methods, experiences & 72 & 40 & 83 & 0 & 0 & 13 & 0 \\
\hline Publicise ESCom in network & 6 & 0 & 0 & 10 & 17 & 25 & 40 \\
\hline Participate in events & 11 & 0 & 0 & 14 & 0 & 13 & 20 \\
\hline
\end{tabular}


Fig. 1 Participation in Ecosystem Services Community Scotland (ESCom) activities between May 2014 and November 2017 used to illustrate different levels of engagement in the community of practice $(\mathrm{CoP})$. Here, the core represents individuals who have attended 5 or more events, active members are those who attended 3 or 4 events and peripheral members are those who attended less than 3 events
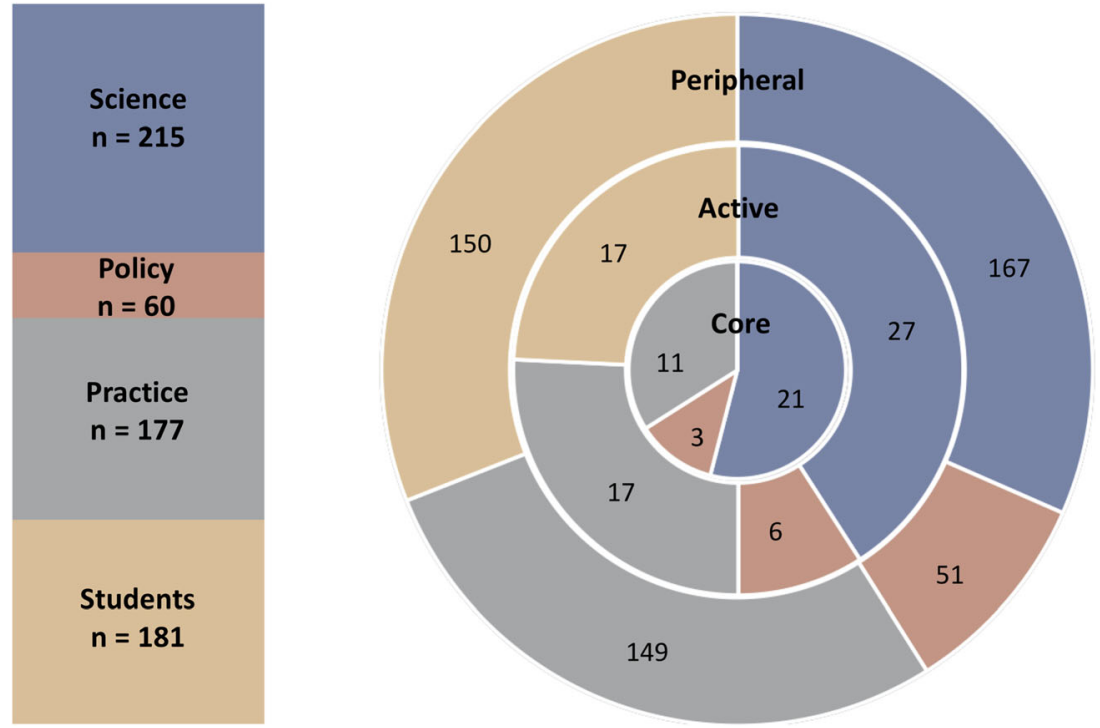

Figure 1 illustrates the breakdown in levels of participation, which follows the indicative ratio between core (10-15\%), active (15-20\%) and peripheral CoP membership indicated by Wenger et al. (2002). Because people will have different levels of interest, it does not make sense to expect equal levels of engagement. Furthermore, participation could be constrained by the support and ability to attend events by employers or supervisors. Although all ESCom events have been free to attend, the financial costs associated with travel cannot be ignored. Members regularly travelled 1-5 hours to attended events (e.g. from Stirling or Aberdeen to Edinburgh). The participation of the four groups reflects the number of individuals within the wider community in Scotland. For example, there are comparatively fewer policy-makers than students working with the ecosystem services framework, whilst there is a large annual cohort of postgraduate students who attend events during their study but are unable to become core members if they then leave Scotland or pursue an unrelated career.

\section{Identity}

A CoP generally forms an informal structure with its own identity that allows its members to connect and develop across organisational or geographic boundaries (Wenger et al. 2002). ESCom has tried to create an identity through branding and fostering an open and inclusive culture.

To make ESCom a visibly active community, the use of the ESCom identity and logo was seen as a community resource that can be used to support and promote collaboration and interaction. This implies a flexible and pragmatic approach, where ESCom branding is encouraged for activities that promote ecosystem services knowledge exchange. ESCom promotes branded events and resources such as new reports and papers to its members, but in return there is the expectation that resources and associated blog or news story are shared on the ESCom website. In the 2016 survey, one Researcher mentioned:

\section{[ESCom] has provided a trusted brand to promote events}

To attract different constituencies who do not regularly interact, it is important to provide a 'safe place' where knowledge, skills and ideas can be shared, explored, adapted and applied (Reed et al. 2014). Building trust is frequently mentioned in the literature as a key aspect of stakeholder engagement in general (Schoonover et al. 2019; Siddiki et al. 2017; de Vries et al. 2017) and CoPs specifically (Brown and Dugin 2001; Wenger et al. 2002). We have therefore tried hard to create a friendly and open culture with ample opportunity for interaction and discussion, both formally and informally. Although difficult to measure quantitatively, positive informal feedback confirmed that this approach is much appreciated by the community (e.g. Table 1, local authority member).

\section{Practice}

The term 'practice' in a CoP refers to communal resources and approaches that create a basis for action, problem solving, communication and accountability, such as case studies, best practices, lessons learned, principles, expert theories and tools (Wengner et al., 2002). We separate these into 'events' that bring the community together and facilitate learning and other 'information sharing' activities that facilitate sharing and developing best practice. 


\section{Events}

Following suggestions at the launch conference, a diverse series of events was organised, including workshops, seminars, site visits, a debate and a panel discussion; together these attracted over 1000 participants, amounting to over 4500 person-hours (Table 2). The events were largely opportunistic. Different organisers ran each event whilst publicity and logistical support were provided by the network manager. The same easily accessible location in central Edinburgh was used in all cases, apart from two site visits and one farmer workshop. Most attendees found events useful and engaging (Fig. 2), valued the networking opportunities, and many attended multiple events.

The recent web-based survey-completed by 50 individuals - revealed that of the 45 individuals that attended one or more events, 96\% were very satisfied or satisfied (Fig. 2; Online Resource 4). Of these events, the seminars and annual conferences were most important to members, followed by training workshops and meetings.

[ESCom events] made me more aware of research which is relevant and connected me with different and new contacts-Public sector agency

[ESCom events] brought innovative research to my attention, helped my networking, shown me practical initiatives - Government policy-maker

\section{Information sharing}

To date ESCom-generated content includes over 20 blogs, 30 news stories, 5 newsletters and over 85 online resources in the form of presentations, briefing notes, workshop reports and videos. ESCom provided valuable knowledge exchange opportunities for Scottish Government-funded research and several European Union-funded research projects working in Scotland focusing on using the ecosystem services framework in nature conservation and sustainable land management. These resources were made available on the website (www. escom.scot) and proved fairly popular (Fig. 2). The latest resource developed with ESCom consortium input is an open access, pictographic ecosystem services map for Scotland that was designed to be used for illustration purposes and as an educational resource (Metzger et al. 2018). From the start, there has been a demand for a central hub that would provide access to synthesised information and news, and also an overview of ongoing research projects and case studies (Online Resource 2), but this has been difficult to maintain without dedicated funding.

So far, ESCom has had to rely on the limited functionality of a basic website, but a dedicated branded micro-site is currently under development within the new ecosystem services knowledge market place, Oppla (www.oppla.eu). This move will allow ESCom members to upload resources and case studies themselves, which will then be accessible to the wider Oppla community. The Oppla search and community functionalities will also improve resource access and facilitate user interaction and discussion.

\section{Reflection and recommendations}

ESCom filled a gap in bringing together diverse constituencies to learn from each other as to how the ecosystem services framework can support better decision-making within Scotland. As noted by one community member, 'ESCom operates at the right scale for building effective partnerships which facilitates trust-building and cooperation, enabling us to share our work with other policy-makers and practitioners in
Fig. 2 Importance of Ecosystem Services Community Scotland (ESCom) activities and products to members from 2018 survey

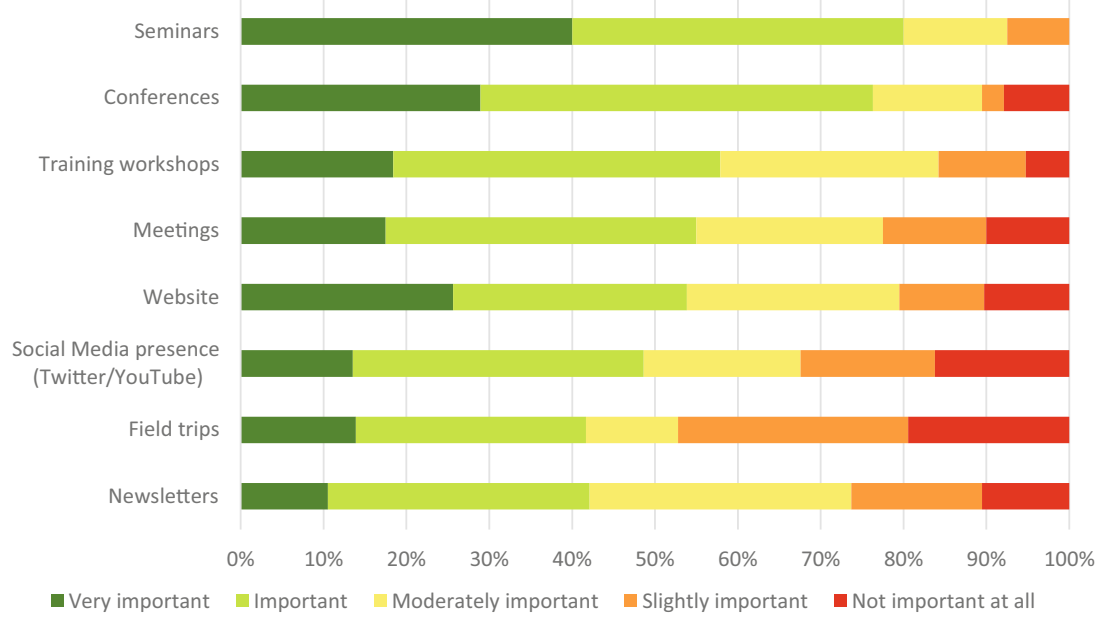


Scotland.' (Table 1). It has successfully brought constituencies together and contributed to aligning research, encouraging collaboration between institutes and improving understanding of policy and practice needs (although these latter objectives are more difficult to measure). However, establishing ESCom has not been without its challenges and we have had to learn and adapt along the way. Here, we reflect on our experiences establishing ESCom to provide recommendations for future ecosystem services CoPs, structured by the principles for cultivating a CoP suggested by Wenger et al. (2002). We also discuss three significant challenges that we are facing to keep ESCom active.

\section{Wenger principles for cultivating communities of practice}

\section{Principle 1: Design for evolution}

Evolution is common to all communities, and the primary role of design is to catalyse this evolution (Wenger et al. 2002). ESCom moved from working groups focused on research collaboration to a much more diverse community with an emphasis on knowledge exchange and networking, supported by a governance structure that assumed significant input from many individuals (Online Resource 3). It proved difficult to maintain this formal structure based on voluntary contributions when supporting projects ended; moving to a simpler governance structure was delayed because it was difficult to ensure agreement when ESCom central governance meetings were poorly attended. The current structure is more flexible, but reliance on a small core team could increase the vulnerability of the CoP to decay from lack of active leadership.

Recommendation 1: Although representation from different types of organisations is desirable, an ecosystem services $\mathrm{CoP}$ aimed at a diverse constituency still requires a simple, flexible and transparent governance structure. Dedicated administrative and communication support is important to keep the $\mathrm{CoP}$ active.

\section{Principle 2: Open dialogue between inside and outside perspectives}

Good community design requires an understanding of the community's potential to develop and steward knowledge, but it often takes an outside perspective to help members see the possibilities (Wenger et al. 2002). From the start ESCom has regularly invited outside speakers and facilitators to events. For example, international academics were invited to provide final reflections at conferences, critical voices were invited to a public debate, and a joint event was organised with the British Ecological Society. Although it was not an explicit strategy, outside perspectives provided fresh thought and motivating recognition. Neutral facilitation has helped in controversial discussions where community members may bias the discussion.

Recommendation 2: Explicitly encourage outside perspectives and critical voices to stay alert to wider developments and gain unexpected insights.

\section{Principle 3: Invite different levels of participation}

People participate in a community for different, non-mutually exclusive reasons: because the community benefits their organisation, for the personal connection, and for the opportunity to improve their skills (Wenger et al. 2002). As illustrated by Fig. 1 and Online Resource 5, ESCom has attracted different levels of participation. However, peripheral members - and outsiders - have made substantial contributions to discussions and contributed to blogs and dialogue on social media. Reasons for infrequent interactions can be varied, and we are aware of individuals who have not been able to engage more actively due to workload and travel distance. ESCom activities have been concentrated in Edinburgh, but we have tried to organise a diversity of events (Online Resource 5) that would interest different audiences.

Recommendation 3: Accept different levels of participation but try to reach out and organise diverse activities that attract a varied audience.

\section{Principle 4: Develop both public and private community spaces}

Dynamic communities are rich with connections that happen both in public space (e.g. during events or on the website) and in private space between community members (Wenger et al. 2002). The "Practice" section describes public spaces created by ESCom, but private spaces were provided as well during events, most notably by providing long breaks to stimulate networking and hosting receptions following events to encourage connections. The new ESCom website will have functionality to support private dimensions as well as enhanced opportunities to share information publicly with the community.

Recommendation 4: Make sure to facilitate private community space during events and virtually, e.g. through social media and web-infrastructure such as Oppla (www.oppla.eu).

\section{Principle 5: Focus on value}

Although the full value of CoPs is often not apparent at formation, providing benefits to their members is key because participation in most communities is self-selected and voluntary (Wenger et al. 2002). Potential benefits of a CoP to (a) organisations include improving outcomes and quality of decisions and developing capabilities and (b) individual community members include access to expertise, gaining confidence 
and strengthening their professional identity (Wenger et al. 2002). ESCom tried to ensure benefits for a wide constituency by including diverse members in its governance structure (Online Resource 3) and asking the community what they would like to see from ESCom (Table 2), which shifted focus over time from research collaboration to more general activities. However, the voluntary nature of the community and limited dedicated funding - approximately 4 hours a week for 3 years for the network manager plus the costs of refreshments at events - has meant we were not able to provide the synthesis reports or coherent overviews of relevant case studies or tools that members have requested. Nevertheless, by aligning activities to longer-term funded research, ESCom has managed to organise a wide variety of activities that attracted over 600 people to spend more than 4500 hours in ESCom events (Online Resource 5). New website functionality will allow members to share content with this large community directly, thus providing additional benefits.

Recommendation 5: Understand how the CoP can provide benefits to different constituencies (i.e. science, policy, practice, students), and be creative and opportunistic by delivering activities through funded research projects and by encouraging members to publicise their work through the CoP.

\section{Principle 6: Combine familiarity and excitement}

Familiarity creates a comfort level that invites candid discussions, but there is also a need for exciting events to provide a sense of common adventure (Wenger et al. 2002). ESCom did not explicitly consider this point, but the organisers of the annual conferences tried to be exciting (which seemed to be appreciated: Fig. 2) and events have concentrated in one central venue easily accessible by public transport, which gives some familiarity. Events such as the public debate, informal 'pie and pint' evening and excursions offered distinctive experiences compared with the more traditional and common mechanisms of engagement, such as conferences, seminars and workshops.

Recommendation 6: Try to organise diverse activities, including some that are novel and different.

\section{Principle 7: Create a rhythm for the community}

Vibrant communities have a rhythm of activity, which should provide a sense of movement and liveliness without being overwhelming (Wenger et al. 2002). ESCom has been formally established for four and a half years and to date the rhythm has focused on the annual conferences and the 'excitement' of the pragmatic and opportunistic events organised by members and the voluntary contributions to the website. The network manager had an instrumental role in coordinating and stimulating these activities.
Recommendation 7: Try to develop a regular schedule of activity and encourage shared responsibility among the community for delivery, but also manage expectations and do not be disheartened when the CoP can only organise a limited number of events.

\section{Challenges}

Wegner's seven principles allowed us to reflect on our experiences establishing ESCom, but we identified three interrelated challenges that remained insufficiently addressed by these principles and led to further recommendations.

\section{Challenge 1: The voluntary nature of a CoP}

ESCom's greatest challenge is to find people willing and able to support the community. Although attendance has always been good (Online Resource 5) and there is continued interest in ESCom activities (Table 2) we have struggled to keep momentum going since support from the project-funded network manager - who devoted approximately four hours a week to ESCom - came to end in November 2017. Despite sincere intentions, people have insufficient time, a recognised challenge in the literature (cf Andrade et al. 2014; Tinch et al. 2018). Partnership building and maintenance are rarely part of job descriptions, making it difficult to justify sustained time commitment (McKee et al. (2018), and non-academic staff have reduced ability to support non-statutory activities under austerity (Kirsop-Taylor 2019). Our experience shows that a low level of continuous support for communication, publicity and event organisation is extremely important to coordinate voluntary commitment and get activities off the ground. The 600 hours of paid support greatly facilitated in achieving > 4500 attendance hours for events (Online Resource 5). Potentially, a more commercial approach, with membership and events fees, could cover these costs but may constrain the diverse membership that we value.

Recommendation 8: Limited funded support for a network manager is necessary to galvanise and maximise voluntary contributions and provides excellent value for money.

\section{Challenge 2: Obtaining institutional commitment to support the CoP}

Despite individuals' desire to increase collaboration, we have observed institutional reticence. Organisations were supportive when ESCom was funded through ongoing research projects, but institutional commitments were never formalisede.g. through a Memorandum of Understanding - hampering structured financial or person-time support. Furthermore, because ESCom is not an established entity it is not explicit who ESCom represents (see also the "Participation" section), and securing institutional support depends on evolving strategic 
opportunities and institutional competition (see Challenge 3). There are great strengths in ESCom's 'grass roots' origins, its organic development, and its inclusive and open nature, but we should arguably have been more aware of the importance of the complex institutional context to secure longer-term support, which mirror critiques of CoPs discussed by Hughes et al. (2007a). It also resonates with Dick et al. (2018) whose international survey of 246 practitioners from 27 ecosystem services project case studies found that institutional change is much more difficult to achieve than change in individual practitioners.

Recommendation 9: Try to achieve inter-institutional commitment to support the CoP to minimise competition and secure shared resourcing.

\section{Challenge 3: Competition with other initiatives}

When ESCom was established, there was limited ecosystem services research in Scotland and transdisciplinary collaboration with policy and practice was in its infancy - this gave a distinct gap and an eagerness for ESCom activities. But in recent years, other initiatives have emerged focusing on overlapping topics and often requiring the commitment and time of the same individuals (e.g. the Scottish Forum on Natural Capital $^{7}$ and SEFARI Gateway ${ }^{8}$ ). For example, SEFARI Gateway was launched in 2017 as the knowledge exchange and impact hub for Scottish Government-funded research, including ecosystem services research. These initiatives have funded network managers (Recommendation 8) and strong institutional support (Recommendation 9). CoPs should transcend institutional competition, but these initiatives crowd-out the availability of community members to support ESCom and may sometimes duplicate the types of products and events previously provided by ESCom. This can generate what has been labelled as 'coopetition' (combining cooperation and competition (Tsai 2002)). Therefore, ESCom should build on its strengths and differentiating characteristics compared to the other initiatives, e.g. its open, informal and diverse membership, its emphasis on embracing students who will influence future policy and practice. Where appropriate and mutually beneficial, ESCom should look for ways to collaborate with these other initiatives on future activities.

Recommendation 10: Differentiate where appropriate and collaborate when appropriate to ensure mutual support among related networks and CoPs.

\footnotetext{
$\overline{7} \mathrm{https} / / /$ naturalcapitalscotland.com

${ }^{8} \mathrm{https}: / /$ sefari.scot/sefari-gateway
}

\section{Conclusion}

The ecosystem services framework has now been embodied in policy and practice, creating the need for governance structures that allow science, policy and practice to come together and facilitate shared learning. ESCom is a $\mathrm{CoP}$ as envisaged by Etienne Wenger (i.e. a social learning partnership) around operationalisation of the ecosystem service framework. As envisaged by CoP theory, ESCom is evolving and will undoubtedly be influenced by the social evolution around ecosystem services both in Scotland and globally in the coming years. We have demonstrated how ESCom has proved valuable to researchers, policy-makers, practitioners and students and as such has contributed to social learning. We also identified challenges given the voluntary nature, absence of formal institutional support and emergence of initiatives focusing on overlapping topics and often requiring the commitment and time of the same individuals. Our ten recommendations will help future ecosystem services CoPs learn from our experiences. Our reflection has also helped us take stock and plan for ESCom's future, including creating better online opportunities to share information and identifying the need to differentiate where appropriate and collaborate when appropriate to ensure mutual support among related networks and CoPs.

Funding information The ESCom network manager was funded by the European Union Seventh Framework Programme (EU FP7) project OPERAs (Grant Agreement No. 308393). ESCom activities were also supported by the EU FP7 projects OpenNESS (Grant Number 308428), GREEN SURGE (Grant Number 603567), the Horizon 2020 project SIMRA (Grant Number 677622), Forestry Commission (UK) funded research on biodiversity and climate change, and the Scottish Government's Strategic Research Programme 2011-2016; 2016-2021. ESCom Central partner organisations provided institutional support.

Open Access This article is distributed under the terms of the Creative Commons Attribution 4.0 International License (http:// creativecommons.org/licenses/by/4.0/), which permits unrestricted use, distribution, and reproduction in any medium, provided you give appropriate credit to the original author(s) and the source, provide a link to the Creative Commons license, and indicate if changes were made.

\section{References}

Abson DJ, von Wehrden H, Baumgärtner S, Fischer J, Hanspach J, Härdtle W, Heinrichs H, Klein AM, Lang DJ, Martens P, Walmsley D (2014) Ecosystem services as a boundary object for sustainability. Ecol Econ 103:29-37. https://doi.org/10.1016/j. ecolecon.2014.04.012

Ainscough J, de Vries Lentsch A, Metzger M, Rounsevell M, Schröter M, Delbaere B, de Groot R, Staes J (2019) Navigating pluralism: understanding perceptions of the ecosystem services Concept. Ecosyst Serv 36:100892. https://doi.org/10.1016/j.ecoser.2019.01.004 
Andrade K, Corbin C, Diver S, Eitzel MV, Williamson J, Brashares J, Fortmann L (2014) Finding your way in the interdisciplinary forest: notes on educating future conservation practitioners. Biodivers Conserv 23:3405-3423. https://doi.org/10.1007/s10531-014-0818-

Baumgärtner S, Becker C, Frank K, Müller B, Quaas M (2008) Relating the philosophy and practice of ecological economics: the role of concepts, models, and case studies in inter- and transdisciplinary sustainability research. Ecol Econ 67:384-393. https://doi.org/10. 1016/j.ecolecon.2008.07.018

Beaumont NJ, Mongruel R, Hooper T (2017) Practical application of the Ecosystem Service Approach (ESA): lessons learned and recommendations for the future. Int J Biodivers Sci Ecosyst Serv Manag 13:68-78. https://doi.org/10.1080/21513732.2018.1425222

Brown JS, Dugin P (2001) Knowledge and organization: a social-practice perspective. Organ Sci 12:198-213. https://doi.org/10.1287/orsc.12. 2.198.10116

Claret C, Metzger MJ, Kettunen M, Ten Brink P (2018) Understanding the integration of ecosystem services and natural capital in Scottish policy. Environ Sci Pol 88:32-38. https://doi.org/10.1016/j.envsci. 2018.05.019

de Vries JR, van Bommel S, Blackmore C, Asano Y (2017) Where there is no history: how to create trust and connection in learning for transformation in water governance. Water 9:130. https://doi.org/ 10.3390/w9020130

Dendoncker N, Turkelboom F, Boeraevev F, Boerema A, Broekx S, Fontaine C, Demeyer R, De Vreese R, Devillet G, Keune H, Janssens L, Liekens I, Lord-Tarte E, Popa F, SimoensI SN, Ulenaers P, Van Herzele A, Van Tichelen K, Jacobs S (2018) Integrating Ecosystem Services values for sustainability? Evidence from the Belgium Ecosystem Services community of practice. Ecosyst Serv 31:68-76. https://doi.org/10.1016/j.ecoser.2018.03. 006

Díaz S, Demissew S, Carabias J, Joly C, Lonsdale M, Ash N, Larigauderie A, Adhikari JR, Arico S, Báldi A, Bartuska A, Baste IA, Bilgin A, Brondizio E, KMA C, Figueroa VE, Duraiappah A, Fischer M, Hill R, Koetz T, Leadley P, Lyver P, Mace GM, MartinLopez B, Okumura M, Pacheco D, Pascual U, Pérez ES, Reyers B, Roth E, Saito O, Scholes RJ, Sharma N, Tallis H, Thaman R, Watson R, Yahara T, Hamid ZA, Akosim C, Al-Hafedh Y, Allahverdiyev R, Amankwah E, Asah TS, Asfaw Z, Bartus G, Brooks AL, Caillaux J, Dalle G, Darnaedi D, Driver A, Erpul G, Escobar-Eyzaguirre P, Failler P, AMM F, Fu B, Gundimeda H, Hashimoto S, Homer F, Lavorel S, Lichtenstein G, Mala WA, Mandivenyi W, Matczak P, Mbizvo C, Mehrdadi M, Metzger JP, Mikissa JB, Moller H, Mooney HA, Mumby P, Nagendra H, Nesshover C, Oteng-Yeboah AA, Pataki G, Roué M, Rubis J, Schultz M, Smith P, Sumaila R, Takeuchi K, Thomas S, Verma M, Yeo-Chang Y, Zlatanova D (2015) The IPBES Conceptual Framework - connecting nature and people. Curr Opin Environ Sustain 14:1-16. https://doi.org/10. 1016/j.cosust.2014.11.002

Dick J, Turkelboom F, Woods H, Iniesta-Arandia I, Primmer E, Saarela SR, Bezák P, Mederly P, Leone M, Verheyden W, Kelemen E, Hauck J, Andrews C, Antunes P, Aszalós R, Baró F, Barton DN, Berry P, Bugter R, Carvalho L, Czúcz B, Dunford R, Garcia Blanco G, Geamănă N, Giucă R, Grizzetti B, Izakovičová Z, Kertész M, Kopperoinen L, Langemeyer J, Montenegro Lapola D, Liquete C, Luque S, Martínez Pastur G, Martin-Lopez B, Mukhopadhyay R, Niemela J, Odee D, Peri PL, Pinho P, Patrício-Roberto GB, Preda E, Priess J, Röckmann C, Santos R, Silaghi D, Smith R, Vădineanu A, van der Wal JT, Arany I, Badea O, Bela G, Boros E, Bucur M, Blumentrath S, Calvache M, Carmen E, Clemente P, Fernandes J, Ferraz D, Fongar C, García-Llorente M, Gómez-Baggethun E, Gundersen V, Haavardsholm O, Kalóczkai Á, Khalalwe T, Kiss G, Köhler B, Lazányi O, Lellei-Kovács E, Lichungu R, Lindhjem H, Magare C, Mustajoki J, Ndege C, Nowell M, Nuss Girona S,
Ochieng J, Often A, Palomo I, Pataki G, Reinvang R, Rusch G, Saarikoski H, Smith A, Soy Massoni E, Stange E, Vågnes Traaholt N, Vári Á, Verweij P, Vikström S, Yli-Pelkonen V, Zulian G (2018) Stakeholders' perspectives on the operationalisation of the ecosystem service concept: results from 27 case studies. Ecosyst Serv 29:552-565. https://doi.org/10.1016/j.ecoser.2017.09.015

Faivre N, Fritz M, Freitas T, de Boissezon B, Vandewoestijne S (2017) Nature-Based Solutions in the EU: innovating with nature to address social, economic and environmental challenges. Environ Res 159: 509-518. https://doi.org/10.1016/j.envres.2017.08.032

Farnsworth V, Kleanthous I, Wenger-Trayner E (2016) Communities of practice as a social theory of learning: a conversation with Etienne Wenger. Brit J Educ Stud 64:139-160. https://doi.org/10.1080/ 00071005.2015.1133799

Hughes J, Jewson N, Unwin L (2007a) Communities of practice: critical perspectives. Routledge, New York

Hughes J Jewson N, Unwin L. (2007b) Conclusion: further developments and unresolved issues. In: Hughes J, Jewson N, Unwin L. (eds.) Communities of practice: critical perspectives. Routledge, New York, pp171-177

Jax K, Furman E, Saarikoski H, Barton DN, Delbaere B, Dick J, Duke G, Görg C, Gómez-Baggethun E, Harrison PA, Maes J, Pérez-Soba M, Saarela S-R, Turkelboom F, van Dijk J, Watt AD (2018) Handling a messy world: lessons learned when trying to make the ecosystem services concept operational. Ecosyst Serv 29:415-427. https://doi. org/10.1016/j.ecoser.2017.08.001

Mauser W, Klepper G, Rice M, Schmalzbauer BS, Hackmann H, Leemans R, Moore H (2013) Transdisciplinary global change research: the co-creation of knowledge for sustainability. Curr Opin Environ Sustain 5:420-431. https://doi.org/10.1016/j.cosust.2013. 07.001

Lave J, Wenger E (1991) Situated learning: legitimate peripheral participation. Cambridge University Press, New York

McKee A, Blackstock K, Azcón JMB, Ciucci P, Hošek M, Huber M, Neubert M, Ritchie C, Sovinc A, Trench H, Végvári Z, Velander K (2018) Developing learning landscape partnerships: why and how to work with protected area managers. Parks 23:63-78. https://doi. org/10.2305/IUCN.CH.2018.PARKS-24-2AMcK.en

Melnykovych M, Nijnik M, Soloviy I, Nijnik A, Sarkki S, Bihun Y (2018) Social-ecological innovation in remote mountain areas: adaptive responses of forest-dependent communities to the challenges of a changing world. Sci Total Environ 613-614:894-906. https://doi.org/10.1016/j.scitotenv.2017.07.065

Metzger MJ Gelfgren S, Allen K, Burton V, Crofton A, Metzger MS, Wilson C, and ESCom (2018) Scotland's natural treasures - an illustrated ecosystem services map, [image]. The University of Edinburgh doi: https://doi.org/10.7488/ds/2321

Mulema AA, Mazur RE (2016) Motivation and participation in multistakeholder innovation platforms in the Great Lakes Region of Africa. Community Dev J 51:212-228. https://doi.org/10.1093/cdj/ bsu068

Nesshöver C, Vandewalle M, Wittmer H, Estelle VB, Carmen E, Geijzendorffer IR, Görg C, Jongman R, Livoreil B, Santamaria L, Schindler S, Settele J, Sousa Pinto I, Török K, van Dijk J, Watt AD, Young JC, Zulka KB, the KNEU Project Team (2016) The Network of Knowledge approach: improving the science and society dialogue on biodiversity and ecosystem services in Europe. Biodivers Conserv 25:1215-1233. https://doi.org/10.1007/s10531-016-11275

Nursey-Bray M, Harvey N, Smith TF (2016) Learning and local government in coastal South Australia: towards a community of practice framework for adapting to global change. Reg Environ Chang 16: 733-746. https://doi.org/10.1007/s10113-015-0779-0

Kirsop-Taylor N (2019) Surviving tough times: an analysis of the strategic responses taken by environmental voluntary sector organisations living under the shadow of austerity. Environ. Polit. in press 
Patton MQ (2011) Developmental evaluation: applying complexity concepts to advance innovation and use. The Guildford Press, New York

Reed MG, Abernethy P (2018) Facilitating co-production of transdisciplinary knowledge for sustainability: working with Canadian biosphere reserve practitioners. Soc Nat Resour 31:39-56. https://doi. org/10.1080/08941920.2017.1383545

Reed MS, Stringer LC, Fazey I, Evely AC, Kruijsen JHJ (2014) Five principles for the practice of knowledge exchange in environmental management. J Environ Manag 146:337-345. https://doi.org/10. 1016/j.jenvman.2014.07.021

Siddiki S, Kim J, Leach WD (2017) Diversity, trust, and social learning in collaborative governance. Public Adm Rev 77:863-874. https://doi. org/10.1111/puar. 12800

Sarkki S, Ficko A, Wielgolaski F, Abraham E, Bratanova-Doncheva S, Grunewald K, Hofgaard A, Holtmeier F-K, Kyriazopoulos A, Broll G, Nijnik M, Sutinen M-L (2017) Assessing the resilient provision of ecosystem services by social-ecological systems: introduction and theory. Clim Res 73:7-15. https://doi.org/10.3354/cr01437

Schoonover H, Grêt-Regamey A, Metzger MJ, Ruiz-Frau A, Santos-Reis M, SSK S, Walz A, Nicholas KA (2019) Creating space, aligning motivations, and building trust: a framework for stakeholder engagement based on experience in 12 ecosystem services case studies. Ecol Soc 24:11. https://doi.org/10.5751/ES-10061-240111
Tinch R, Balian E, Carss D, de Blas DE, Geamana NA, Heink U, Keune H, Nesshöver C, Niemelä J, Sarkki S, Thibon M, Timaeus J, Vadineanu A, van den Hove S, Watt A, Waylen KA, Wittmer H, Young JC (2018) Science-policy interfaces for biodiversity: dynamic learning environments for successful impact. Biodivers Conserv 27:1679-1702. https://doi.org/10.1007/s10531-016-1155-1

Tsai W (2002) Social structure of "coopetition" within a multiunit organization: coordination, competition, and intraorganizational knowledge sharing. Organ Sci 13:109-222. https://doi.org/10.1287/orsc. 13.2.179.536

Waylen K Backstock K, Holstead K (2013) Exploring experiences of the Ecosystem Approach. James Hutton Institute report. Available here: http://www.hutton.ac.uk/sites/default/files/files/snc/Report\%20on\% 20EcA\%20review\%20Final.pdf (Accessed 5 May 2018)

Wenger E, McDermott R, Snyder WM (2002) Cultivating communities of practice: a guide to managing knowledge. Harvard Business School Publishing, Cambridge

Publisher's note Springer Nature remains neutral with regard to jurisdictional claims in published maps and institutional affiliations.

\section{Affiliations}

\section{Marc J. Metzger ${ }^{1}$ (D) $\cdot$ Jan Dick $^{2} \cdot$ Abi Gardner $^{1} \cdot$ Chloe Bellamy $^{3} \cdot$ Kirsty Blackstock $^{4} \cdot$ Calum Brown $^{1,5}$. Rachel Chisholm ${ }^{1}$. Phoebe Cochrane ${ }^{6}$. Joanna Drewitt ${ }^{7}$. Alessandro Gimona ${ }^{4}$ - Alison Hester ${ }^{4} \cdot$ Scot Mathieson $^{8}$. Maria Nijnik ${ }^{4}$ - Alistair McVittie ${ }^{9} \cdot$ Michal Petr $^{3} \cdot$ Ron Smith $^{2} \cdot$ Mike Smith $^{10}$}

1 School of GeoSciences, The University of Edinburgh, Drummond St., Edinburgh EH8 9XP, Scotland, UK

2 Centre for Ecology \& Hydrology, Bush Estate, Penicuik, Midlothian EH26 0QB, Scotland, UK

3 Northern Research Station, Forest Research, Centre for Ecosystems, Society and Biosecurity, Roslin, Midlothian EH25 9SY, Scotland, UK

4 James Hutton Institute, Craigiebuckler, Aberdeen AB158QH, Scotland, UK

5 Karlsruhe Institute of Technology, Institute of Meteorology and Climate Research, Atmospheric Environmental Research (IMK-
IFU), Kreuzeckbahnstraße 19, 82467 Garmisch-

Partenkirchen, Germany

6 Scottish Environment LINK, 4 Hunter Square, Edinburgh EH1 1QW, Scotland, UK

7 Scottish Government, Victoria Quay, Commercial Street, Edinburgh EH6 6QQ, Scotland, UK

8 Scottish Environment Protection Agency, Strathallan House, The Castle Business Park, Stirling FK9 4TZ, Scotland, UK

9 SRUC, West Mains Road, Edinburgh EH9 3JG, Scotland, UK

10 EcoSol, 2 Newmill Cottages, Slitrig, Hawick TD9 9UQ, Scotland, UK 